UDC $66.974 .434+544.723 .21+544.723 .23+544.723 .3$

M.O. Chaban ${ }^{a}$, L.M. Rozhdestvenska ${ }^{a}$, O.V. Palchik ${ }^{a}$, L.M. Ponomarova ${ }^{b}$, Y.S. Dzyazko ${ }^{a}$

\title{
SELECTIVE TO LITHIUM IONS NANOCOMPOSITE SORBENTS BASED ON TiO CONTAINING MANGANESE SPINEL
}

\author{
${ }^{\text {a }}$ V.I. Vernadsky Institute of General and Inorganic Chemistry of National Academy of Sciences of \\ Ukraine, Kyiv, Ukraine

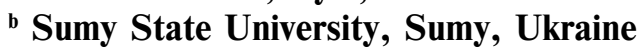

\begin{abstract}
A method for obtaining nanocomposite sorbents, which are selective towards $\mathrm{Li}^{+}$ions, has been proposed. The samples were based on adsorptive-active anatase, the selective component being lithium-manganese spinel $\mathrm{LiMn}_{2} \mathrm{O}_{4}$. This component was synthesized preliminarily, its nanoparticles were added to the sol of insoluble titanium hydroxocomplexes, and the nanocomposite was precipitated from this suspension and calcined at $500^{\circ} \mathrm{C}$. A number of sorbents with different molar ratio of Ti:Mn were prepared via this procedure; they were investigated by means of chemical analysis, X-ray diffraction analysis, optical microscopy, transmission electron microscopy and scanning electron microscopy. The size of nanocrystallites was $20-30 \mathrm{~nm}$. An increase in the spinel amount caused a decrease in the sorbent grain size; however, they the sorbent grains were mechanically durable due to $\mathrm{TiO}_{2}$ which was a binder. Adsorption of $\mathrm{Li}^{+}$from the solution containing an excess of $\mathrm{Na}^{+}$ions was studied. The optimal amount of $\mathrm{LiMn}_{2} \mathrm{O}_{4}(13 \%)$ was determined. The sample was obtained in the form of rather large grains $(\approx 0.3 \mathrm{~mm})$ and the selectivity coefficient $\mathrm{Li}^{+} / \mathrm{Na}^{+}$was about 500 . The sorbent was regenerated by a $1 \mathrm{M} \mathrm{HNO}_{3}$ solution without manganese leakage. After 10 cycles of sorption-desorption, the concentrate was obtained. This concentrate can be used for $\mathrm{Li}_{2} \mathrm{CO}_{3}$ precipitation.
\end{abstract}

Keywords: anatase, spinel, nanocomposite, lithium, adsorption.

DOI: $10.32434 / 0321-4095-2021-137-4-126-133$

\section{Introduction}

Lithium and its compounds are used to produce alloys, thermoelectric, optical and laser materials [1]. They are also used in medicine, metallurgy and pyrotechnics. Nowadays, the usage of lithium in chemical power sources is in a focus of attention. In 2020, the demand for lithium will be more than 20,000 tons (lithium carbonate equivalents) [2]. This metal is contained in water of some salt lakes, the most salars known being located mainly in South America. Some minerals, such as spodumene, petalit and ambligonit, also contain lithium and used for producing this metal. Lithium-ion batteries are secondary sources of lithium: the technologies for their recycling have been already developed [3]. The development of lithium deposits (salars) and the recovery of lithium from primary and secondary resources cause ecological risks [4]: alienation of fertile lands, salinization of fresh water sources, high consumption of fresh water and its pollution with soluble lithium compounds (maximal allowable concentration is $0.03 \mathrm{mg} \mathrm{dm}^{-3}$ ) and other toxic additions.

Sea water [5] and mine water [6] are considered as alternative lithium sources despite the low content of this metal $\left(0.1-0.2 \mathrm{mg} \mathrm{dm}^{-3}\right)$. In this case, sorption method involving lithium-selective sorbents are attractive. Such inorganic sorbents as lithium titanates and manganates, which are preliminarily converted into $\mathrm{H}$-forms, are the most widespread [7-9]. The sorbents are characterized by spinel structure. As a rule, sorption of ions by inorganic sorbents is due to the substitution of counter-ions of functional groups (ion exchange); sometimes ion exchange is accompanied by additional interaction of sorbed ions with these groups. This is confirmed directly with spectroscopic methods [10] or indirectly by modeling kinetic curves of sorption [11]. As opposed to the traditional ion exchange, the mechanism of lithium sorption on spinels involves not only ion exchange

(C) M.O. Chaban, L.M. Rozhdestvenska, O.V. Palchik, L.M. Ponomarova, Y.S. Dzyazko, 2021

M.O. Chaban, L.M. Rozhdestvenska, O.V. Palchik, L.M. Ponomarova, Y.S. Dzyazko 
(adsorption on nanocrystallite surface), but also intercalation to octahedral spaces between octahedrons [12].

The disadvantage of spinels is fine dispersion: it is difficult to use them as a filler of sorption column. This problem can be solved via the development of nanocomposites containing a binder that is also able to sorb $\mathrm{Li}^{+}$ions. Earlier, we prepared coarse dispersive nanocomposites containing simultaneously $\mathrm{TiO}_{2}$ and $\mathrm{Li}_{0.75} \mathrm{Mn}_{0.25} \mathrm{Ti}_{2} \mathrm{O}_{4}$ [12]. They were used for sorption [13] and electromembrane [14] recovery of $\mathrm{Li}^{+}$ions from the solution that also contained an excess of $\mathrm{Na}^{+}$and $\mathrm{K}^{+}$ions. In the nanocomposite, the binder $\left(\mathrm{TiO}_{2}\right)$ is in a form of rutile [12], which is less adsorptive inert material than anatase [15]. The procedure of the nanocomposite synthesis involved formation of spinel in hydrated double dioxide of $\mathrm{Ti}$ and $\mathrm{Mn}$ under calcination of this sorbent. It had been preliminarily impregnated with $\mathrm{LiOH}$ solution.

The aim of this work is to develop anatasebased nanocomposites containing Li-selective spinel. Their sorption properties were investigated.

\section{Experimental}

\section{Hydrous titanium dioxide}

For the synthesis of a macroporous sample of hydrous titanium dioxide (HTD) and composites based on HTD, a sol of insoluble titanium hydrocomplexes was used which was obtained by electrochemical method. To this end, $1 \mathrm{M} \mathrm{TiCl}_{4}$ solution was used and $\mathrm{ZrOCl}_{2}$ was added to stabilize it. The molar ratio of Ti: $\mathrm{Zr}$ was 1:0.05. A twochamber cell was used for electrodialysis, its electrodes were made of platinum titanium. A cation exchange membrane was utilized to separate the anode and cathode spaces. The distance between the membrane and each electrode was $1 \mathrm{~cm}$, the cross section of each chamber was $4 \mathrm{~cm}^{2}$, and their height was $4 \mathrm{~cm}$. The working area of the membrane was $16 \mathrm{~cm}^{2}$. Electrodialysis was carried out at the current density of $250 \mathrm{~A} \mathrm{~m}^{-2}$. Turbidity of the titanium-containing solution was detected after $5 \mathrm{~h}$ with a Tyndall cone observed by means of laser irradiation, which indicated the formation of a colloidal solution. The content of $\mathrm{Cl}^{-}$ions was determined using the ionometer I-160MI, equipped with a Cl-selective electrode ELIS $131 \mathrm{Cl}$; it reached a minimum value.

\section{Hydrous manganese dioxide}

Hydrous manganese dioxide (HMD) was obtained by the following reaction:

$2 \mathrm{KMnO}_{4}+3 \mathrm{MnSO}_{4}+2 \mathrm{H}_{2} \mathrm{O} \rightarrow 5 \mathrm{MnO}_{2}+\mathrm{K}_{2} \mathrm{SO}_{4}+2 \mathrm{H}_{2} \mathrm{SO}_{4}$.

Sulfuric acid that is formed promotes the dissolution of $\mathrm{Mn}_{2} \mathrm{O}_{3}$ impurities, which are formed as a by-product:

$$
\mathrm{Mn}_{2} \mathrm{O}_{3}+\mathrm{H}_{2} \mathrm{SO}_{4} \rightarrow \mathrm{MnO}_{2} \downarrow+\mathrm{MnSO}_{4}+\mathrm{H}_{2} \mathrm{O} .
$$

Adiabatic drying was used for HMD and benzene was used as a working fluid. The resulting xerogel was mixed with solid $\mathrm{LiOH}$, the molar ratio of $\mathrm{Li} / \mathrm{Mn}$ was 1:2. The mixture was calcined for $5 \mathrm{~h}$ at $400^{\circ} \mathrm{C}$, cooled to room temperature, ground again and then calcined at $600^{\circ} \mathrm{C}$.

\section{Sorbents containing manganese spinel}

Lithium manganate was introduced into a freshly prepared sol of titanium hydroxocomplexes. The molar ratio of Ti:Mn was 1:0.05, 1:0.1, 1:0.2, $1: 0.3,1: 0.4,1: 0.5$, and 1:1. The suspension was sonicated for $5 \mathrm{~min}$ using a Bandelin device and immediately dispersed through a capillary to a column filled with immiscible liquids: n-heptane and concentrated $\mathrm{NH}_{4} \mathrm{OH}$ solution. The obtained granules were washed with water until the eluate was neutral, dried adiabatically with benzene, calcined at $500^{\circ} \mathrm{C}$, treated with $1 \mathrm{M} \mathrm{HNO}_{3}$ solution and washed again with deionized water.

\section{Characterization of sorbents}

Chemical analysis was performed by an X-ray fluorescent spectrometer X-Supreme 8000 XRF (Oxford Instruments). Microphotographs were obtained by using a Trek DCM510 camera with a RL05-48 ring diode illuminator attached to a PZO optical microscope (PZO, Poland). The particle size distributions were plotted as dependencies of particle fraction $(W)$ on grain size $(d)$, where $W_{i}=q_{i} / \sum_{i=1} q_{i}$, $q$ is the amount of particles of one or the other size, $i$ is the integer $\left(\sum_{i=1} q_{i}=300\right)$.

Transmission electron microscopy (TEM) images of granules were obtained by using a transmission microscope JEOL JEM 1230 (JEOL, Japan). Scanning electron microscope (SEM) Tescan Mira 3 LMU (Czech Republic) was also used. For thermogravimetric analysis of spinel, a Derivatograph Q-1500 (Paulik-Paulik-Erdei system, Hungary) was used. The heating rate was 5 degree $\mathrm{min}^{-1}$.

For X-ray analysis, a diffractometer DRON-3M (LOMO, RF) with external standards certified by $\mathrm{SiO}_{2}$ (standard 20) and $\mathrm{Al}_{2} \mathrm{O}_{3}$ (intensity standard) was used (Cu-radiation, Ni-filter). Pore volume and specific surface area were determined by a method of nitrogen adsorption and desorption using an automatic gas adsorption analyzer Quantachrome 
AS1Win (Quantachrome Instruments, USA). Calculations were performed according to the BET model.

Investigation of sorption and regeneration

Sorption studies were performed using a twocomponent solution containing $0.01 \mathrm{~mol} \mathrm{dm}^{-3} \mathrm{LiCl}$ and $0.5 \mathrm{~mol} \mathrm{dm}^{-3} \mathrm{NaCl}$. The solution was pre-basified to $\mathrm{pH} 10$ with lithium hydroxide. The $4 \mathrm{~g} \mathrm{dm}^{-3}$ dosage of the sorbent was left overnight, then decanted, washed with deionized water and left overnight with $1 \mathrm{M} \mathrm{HNO}_{3}$ for desorption. Then equilibrium and desorption solutions were analyzed. Under these conditions, complete saturation of sorbents with ions occurs, which is possible at the specified $\mathrm{pH}$ value. $\mathrm{Li}^{+}$and $\mathrm{Na}^{+}$ions in the solution were determined using a PYE UNICAM SP 9 atomic absorption spectrometer (Philips) and a PFM-U4 flame photometric device (Analytpribor, Belarus), respectively.

Regeneration of the sample with the optimal molar ratio of $\mathrm{Mn}: \mathrm{Ti}$ (0.3:1) was investigated, its $\mathrm{H}$ form being preliminarily loaded with $\mathrm{Li}^{+}$ions under dynamic conditions using $0.1 \mathrm{M} \mathrm{LiCl}$ solution. After loading, the sorbent was washed with deionized water, the volume of which was equal to the bed volume. The sorbent was removed from the columns and dried down to constant weight. Several weighted samples were moved to flasks containing deionized water or $1 \mathrm{M}$ solutions of $\mathrm{NaOH}, \mathrm{HNO}_{3}, \mathrm{HCl}$ and $\mathrm{H}_{2} \mathrm{SO}_{4}$. The sorbent dosage was $10 \mathrm{~g} \mathrm{dm}^{-3}$. The solution was analyzed after $48 \mathrm{~h}$ and residual sorption capacity (A) was determined. The regeneration degree was calculated as $100 \% \cdot\left(\mathrm{A}_{0}-\mathrm{A}\right) / \mathrm{A}_{0}$.

Multiple sorption-regeneration was performed. For sorption, a model solution containing $\mathrm{Na}^{+}$ $\left(252 \mathrm{mmol} \mathrm{dm}^{-3}\right), \mathrm{K}^{+}\left(5 \mathrm{mmol} \mathrm{\textrm {dm } ^ { - 3 }}\right)$ and $\mathrm{Li}^{+}$ $\left(0.014 \mathrm{mmol} \mathrm{dm}^{-3}\right)$, which corresponds to the composition of sea water (without hardness ions). Previous investigations showed that hardness ions reduce the sorption of $\mathrm{Li}^{+}$, so it is recommended to preliminary remove those ions from solution. The solution was passed through the column (with a column diameter of $1.3 \mathrm{~cm}$ and sorbent layer of $42 \mathrm{~cm}$ ), and then the sorbent was washed with water. Then, a $1 \mathrm{M} \mathrm{HNO}_{3}$ solution (solution I, five bed volumes) was circulated through the column for $36 \mathrm{~h}$. After that, a fresh regenerating solution II was circulated for $4 \mathrm{~h}$ (two bed volumes). Then, the sorbent was washed with deionized water again, and the next sorption-desorption cycle was carried out. The same solution was used for regeneration during 10 cycles.

\section{Results and discussion}

Structure of prepared materials

First, the phase transformations of the sorbent obtained from HMD were studied. Figure 1 shows the data of thermogravimetric analysis. A slight loss of unbound water is observed up to $70^{\circ} \mathrm{C}$. Then, there is a loss of unbound and bound water as well as water released by condensation of $-\mathrm{OH}$ groups. These processes correspond to the endopeak at $250^{\circ} \mathrm{C}$. A small exopeak at $580^{\circ} \mathrm{C}$ refers to crystallization. At the temperature of about $530^{\circ} \mathrm{C}$, the following transformation occurs:

$$
4 \mathrm{MnO}_{2} \rightarrow 2 \mathrm{Mn}_{2} \mathrm{O}_{3}+\mathrm{O}_{2} \uparrow .
$$

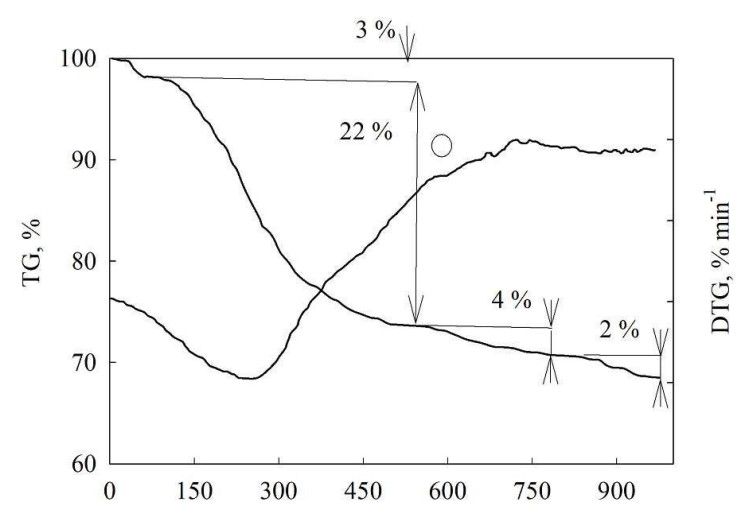

Fig. 1. Data of thermogravimetric analysis of HMD Li-form. The circle indicates the exopeak, which corresponds to the formation of $\mathrm{LiMn}_{2} \mathrm{O}_{4}$

Although this effect is not detected on the derivatogram, XRD analysis shows the presence of $\mathrm{Mn}_{2} \mathrm{O}_{3}$ traces (Fig. 2,a). The addition of spinel to HTD followed by calcination at $600^{\circ} \mathrm{C}$ leads to the formation of composite: the diffracrograms reveal the signals that are characteristic of anatase (as opposed to the nanocomposite obtained from double Ti-Mn oxide [12]) and lithium-manganese spinel $\mathrm{LiMn}_{2} \mathrm{O}_{4}$ (Fig. 2,b). In this case, no $\mathrm{Mn}_{2} \mathrm{O}_{3}$ traces are observed.

The introduction of spinel into $\mathrm{TiO}_{2}$ at the stage of amorphous HTD formation (Fig. 3) leads to a decrease in the size of the granules of the $\mathrm{LiMn}_{2} \mathrm{O}_{4}$ nanocomposite (i.e. after calcination, Fig. 4). The typical Gaussian size distributions of the granules are observed, which shift to the region of smaller grain sizes with increasing spinel content. At a high content of spinel (Ti:Mn=1:1), fine powder is formed, the particle size is less than $0.1 \mathrm{~mm}$. The spinel specks are seen on the grain surface (Fig. 5,a): The specks are black with a metallic luster. As seen from Fig. 3, the spinel nanocrystallites $(10-20 \mathrm{~nm})$ are 


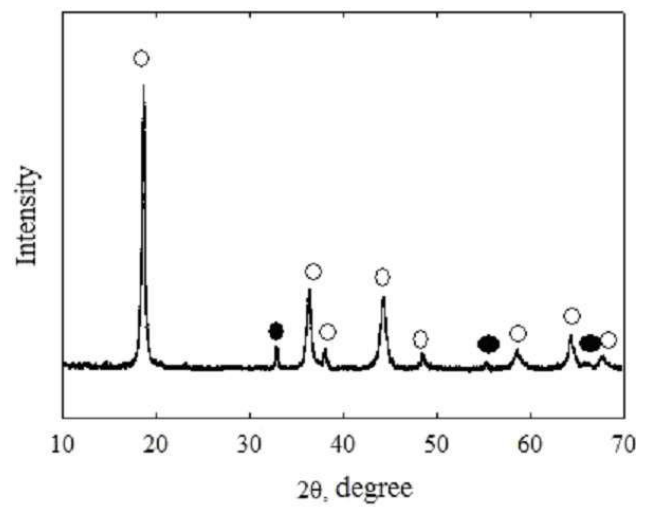

$\mathbf{a}$

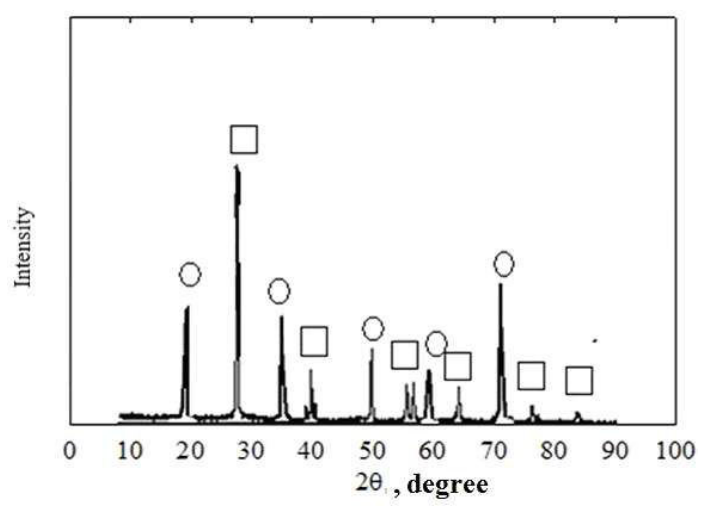

b

Fig. 2. X-ray diffraction pattern: a - $\mathrm{LiMn}_{2} \mathrm{O}_{4}$ spinel (white circles) containing $\mathrm{Mn}_{2} \mathrm{O}_{3}$ traces (black circles), and b - composite containing anatase (squares) and $\mathrm{LiMn}_{2} \mathrm{O}_{4}$ (circles)

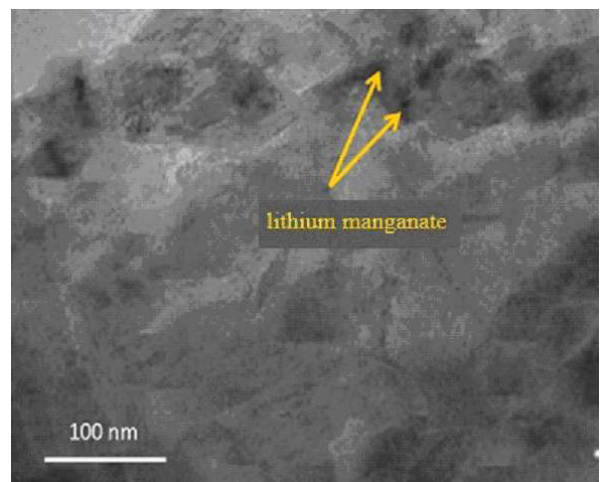

Fig. 3. TEM image of nanocomposite containing HTD and $\mathrm{LiMn}_{2} \mathrm{O}_{4}$ (before calcination)

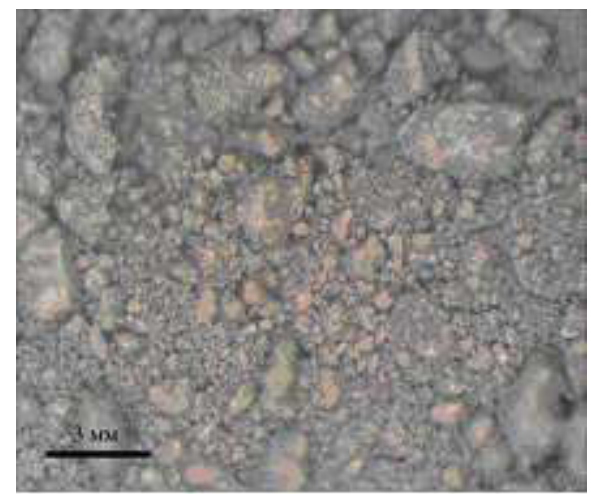

a

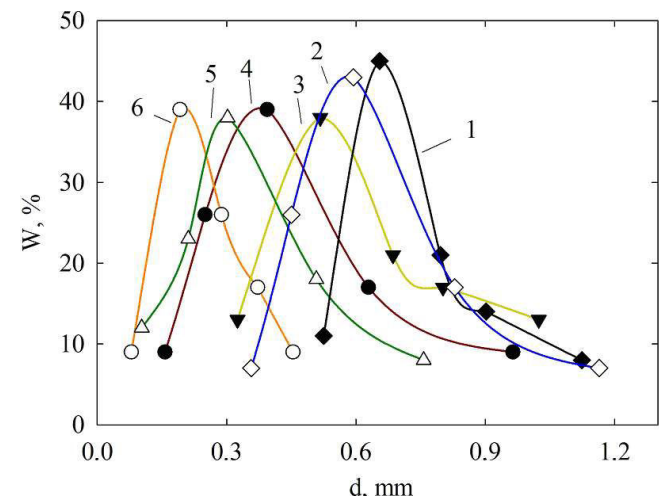

Fig. 4. Particle size distribution of the sorbents: $\mathrm{TiO}_{2}(1)$ and $\mathrm{TiO}_{2}$ containing spinel $\mathrm{LiMn}_{2} \mathrm{O}_{4}(2-6)$. The molar ratio of Ti: Mn was 1:0 (1), 1:0.05 (2), 1:0.1 (3), 1:0.2 (4), 1:0.3 (5) and $1: 0.4(6)$

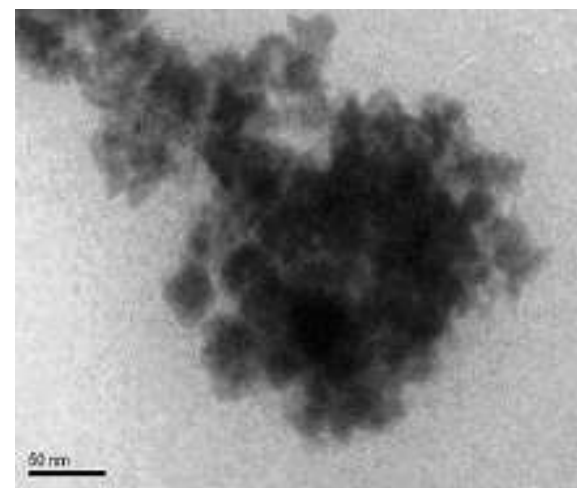

b

Fig. 5. a - Micrograph of composite granules and b - TEM image of the original spinel nanoparticles incorporated into $\mathrm{TiO}_{2}$. The molar ratio of Ti:Mn was 1:1 (a) and 1:0.05 (b)

also distributed in the bulk of HTD. These particles are more contrasting than $\mathrm{TiO}_{2}$ particles and shade them. It is the same for the calcined nanocomposite (Fig. 5,b).

The mechanical abrasion strength of $\mathrm{TiO}_{2}$ is $90 \%$. The addition of spinel at a molar ratio of
Ti:Mn=1:0.05 practically does not impair the strength. A slight deterioration is also observed for the sample with the ratio Ti:Mn=1:0.2 (i.e. $85 \%$ ). For the sorbent with a higher content of $\mathrm{Mn}$ $(\mathrm{Ti}: \mathrm{Mn}=1: 0.4)$, much lower abrasion resistance $(61 \%)$ was found. 


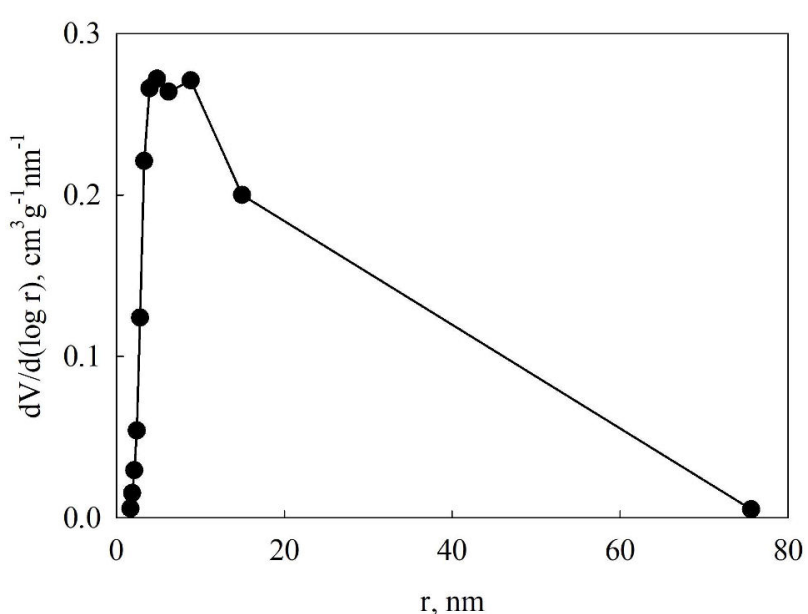

Fig. 6. Differential pore size distribution of $\mathrm{LiMn}_{2} \mathrm{O}_{4}$

Lithium spinel shows a mesoporous structure. In the differential pore size distribution, two closely located peaks (at 5 and $10 \mathrm{~nm}$ ) are visible (Fig. 6). As opposed to calcined titanium dioxide, the specific surface area of lithium spinel is four times lower due to inconsiderable microporosity (Table 1): the order of magnitude of the volume of micropores is only $10^{-3} \mathrm{~m}^{2} \mathrm{~g}^{-1}$. This additive causes a slight decrease of the mesoporosity contribution to the total pore volume, which is determined by a method of nitrogen adsorption-desorption. Comparing with $\mathrm{TiO}_{2}$, the reduction of the specific surface area reaches $33 \%$ when the molar ratio of Ti:Mn is 1:0.4.

Table 1

Influence of $\mathrm{LiMn}_{2} \mathrm{O}_{4}$ content on the porous structure of $\mathrm{TiO}_{2}$

\begin{tabular}{|c|c|c|c|c|}
\hline \multirow{2}{*}{$\begin{array}{l}\text { Molar ratio } \\
\text { Ti:Mn }\end{array}$} & \multicolumn{3}{|c|}{ Volume, $\mathrm{cm}^{3} \mathrm{~g}^{-1}$} & \multirow{2}{*}{$\begin{array}{c}\text { Specific } \\
\text { surface area } \\
\mathrm{m}^{2} \mathrm{~g}^{-1}\end{array}$} \\
\hline & micropore & mesopores & total & \\
\hline $1: 0\left(\mathrm{TiO}_{2}\right)$ & 0.23 & 0.05 & 0.29 & 290 \\
\hline $0: 1\left(\mathrm{LiMn}_{2} \mathrm{O}_{4}\right)$ & $2.31 \cdot 10^{3}$ & 0.23 & 0.23 & 73 \\
\hline $1: 0.05$ & 0.22 & 0.05 & 0.29 & 280 \\
\hline 1: & 0.20 & 0.04 & 0.24 & 265 \\
\hline $1: 0$ & 0.18 & 0.04 & 0.22 & 240 \\
\hline 1: & 0.13 & 0.03 & 0.16 & 218 \\
\hline $1: 0.4$ & 0.11 & 0.03 & 0.14 & 193 \\
\hline
\end{tabular}

The positive effect of low microporosity may be the lack of selective sorption centers for hardness ions and alkaline metal ions. Sorption of $\mathrm{Li}^{+}$ions should occur through intercalation and adsorption on the surface of primary nanoparticles [8].

Sorption properties of nanocomposites

The sorption capacity (A) of the fine sample $\mathrm{LiMn}_{2} \mathrm{O}_{4}$, previously converted to hydrogen form, was $2.3 \mathrm{mmol} \mathrm{g}-1$ and $1 \mathrm{mmol} \mathrm{g}-1$ for $\mathrm{Li}^{+}$and $\mathrm{Na}^{+}$ ions, respectively. Thus, the total capacity at $\mathrm{pH}$ 10 was $3.3 \mathrm{mmol} \mathrm{g}^{-1}$, and the selectivity coefficients $\left(\mathrm{K}_{\mathrm{s}}\right)$ was 1000 (here $\mathrm{K}_{\mathrm{s}}=\frac{\mathrm{A}_{\mathrm{Li}} \mathrm{C}_{\mathrm{Na}}}{\mathrm{A}_{\mathrm{Na}} \mathrm{C}_{\mathrm{Li}}}$, and $\mathrm{C}$ is the ion concentration in the solution). A shift of the $\mathrm{pH}$ value to the acidic region indicates ion exchange mechanism of adsorption on the surface of primary particles. Spinel nanoparticles in anatase improve sorption properties of the nanocomposites, as the spinel content in the samples increases (Fig. 7, here the A value is a function of the ratio of the molar concentration of $\mathrm{Mn}$ and $\mathrm{Ti}$ in the samples). However, the growth rate of the capacity slows down, which is obviously due to mutual shielding of the surfaces of anatase and spinel nanoparticles. As a result, the part of the surface containing the functional groups becomes inaccessible.

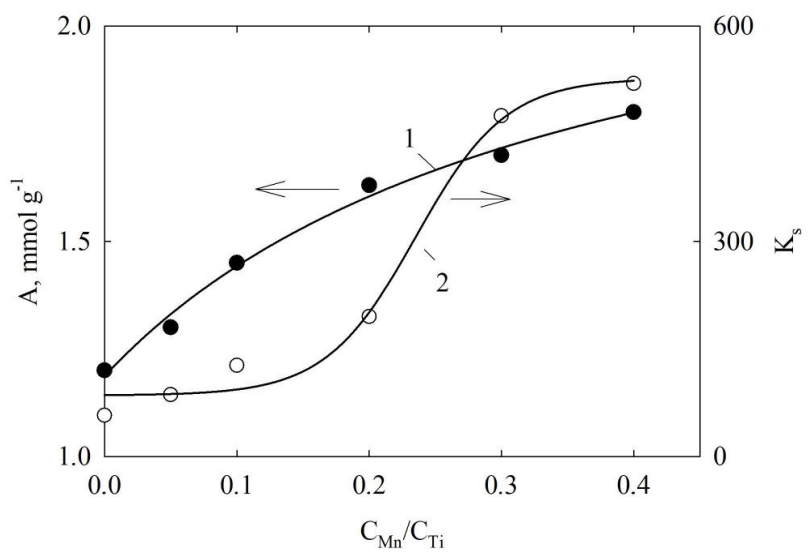

Fig. 7. Dependence of the summary sorption capacity towards $\mathrm{Li}^{+}$and $\mathrm{Na}^{+}$ions (1) and $\mathrm{Li}^{+} / \mathrm{Na}^{+}$selectivity coefficients (2) on the molar ratio of $\mathrm{Mn}$ and $\mathrm{Ti}$ ratio in sorbents

This shielding determines the percolation nature of the dependence of the selectivity coefficient on the $\mathrm{C}_{\mathrm{Mn}} / \mathrm{C}_{\mathrm{Ti}}$ parameter due to the effect of intercalation enhances with increasing spinel content in the samples. The dependence is approximated by a sigmoidal function: for samples with low spinel content, a slow increase in selectivity is observed, followed by a sharp growth, and finally a slight increase in the $K_{s}$ value is visible. The percolation threshold can be explained by a sharp decrease in anatase micropores volume due to their shielding with spinel nanocrystallites. Such micropores act as centers for selective sorption of $\mathrm{Na}^{+}$ions. Therefore, the contribution of sorption due to intercalation and adsorption of $\mathrm{Li}^{+}$on the surface of spinel and anatase nanocrystallites is enhanced. Indeed, in comparison 
with the sample, for which $\mathrm{C}_{\mathrm{Mn}} / \mathrm{C}_{\mathrm{Ti}}=0.2$, the reduction in the volume of micropores is $28 \%$ for a sorbent with higher spinel content $\left(\mathrm{C}_{\mathrm{Mn}} / \mathrm{C}_{\mathrm{Ti}}=0.3\right)$, as follows from Table 1. This decrease is the largest one among the studied samples.

A sample with molar ratio Ti:Mn=1:0.3 (spinel content is $13 \%$ ) was chosen for practical use. In this case, relatively large granules are formed (Fig. 4). This sample displays high selectivity towards $\mathrm{Li}^{+}$ions. A further increase in the spinel content leads to a slight improvement in selectivity. Moreover, smaller granules are formed, and they are mechanically unstable. Thus, the optimal content of spinel is $13 \%$. Further regeneration of this sample was studied.

First of all, the regenerating solution was chosen. Trace amounts of $\mathrm{Li}^{+}$ions in deionized water is due to leakage of the residual solution from pores (Fig. 8). Desorption of $\mathrm{Li}^{+}$in alkaline solution is caused by $\mathrm{Na}^{+} \rightarrow \mathrm{Li}^{+}$exchange, here the adsorbed $\mathrm{Li}^{+}$ions leave the surface of primary particles. The sorbent is completely regenerated by a $1 \mathrm{M} \mathrm{H}_{2} \mathrm{SO}_{4}$ solution, however, the losses of manganese are $0.12 \%$ and $0.18 \%$ with respect to the total sorbent mass at $20^{\circ} \mathrm{C}$ and $45^{\circ} \mathrm{C}$, respectively. The losses are less in the case of $\mathrm{HCl}$ solution $\left(0.08 \%\right.$ and $0.1 \%$ at $20^{\circ} \mathrm{C}$ and $45^{\circ} \mathrm{C}$, respectively). The reduction of $\mathrm{Mn}$ (IV) occurs and it is accompanied by the evolution of $\mathrm{O}_{2}$ (in $\mathrm{H}_{2} \mathrm{SO}_{4}$ ) or $\mathrm{Cl}_{2}$ (in $\mathrm{HCl}$ ). Manganese leakage means deterioration of the sorbent selectivity during multiple uses. At the same time, no manganese traces were found in a $1 \mathrm{M} \mathrm{HNO}_{3}$ solution. The regenerating solution of this composition was used further for multiple sorption-regeneration. In order to achieve complete desorption, fresh regenerating solution was used (solution II). This approach was applied to multiple sorption-desorption.

For the first sorption cycle, the capacity $\left(\mathrm{A}_{1}\right)$ reached $\left(\mathrm{mmol} \mathrm{g}^{-1}\right)$ : $\mathrm{Li}^{+}-0.032, \mathrm{Na}^{+}-0.12$, and $\mathrm{K}^{+}-0.005$. The ratios of capacities $\left(\mathrm{A} / \mathrm{A}_{1}\right.$, where $\mathrm{A}$ is the capacity in the next sorption cycles) are given

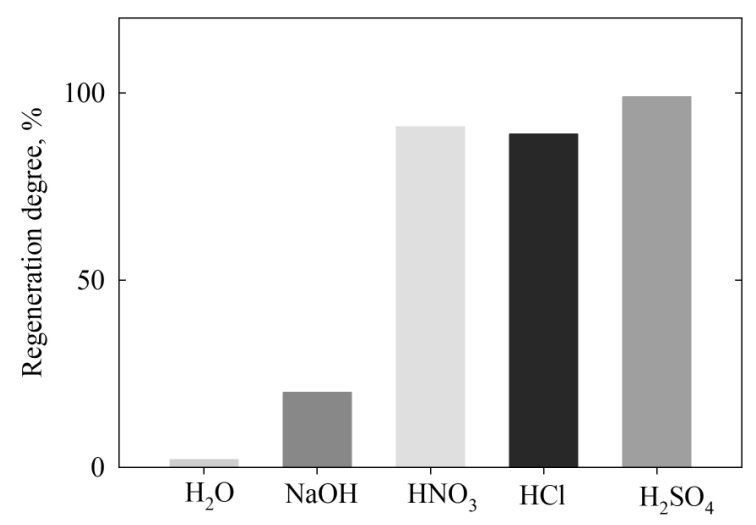

Fig. 8. Regeneration of the sorbent containing $\mathrm{LiMn}_{2} \mathrm{O}_{4}$
Table 2

Multiple sorption-desorption of $\mathrm{Li}^{+}$on the composite containing $13 \%$ of $\mathrm{LiMn}_{2} \mathrm{O}_{4}$

\begin{tabular}{|c|c|c|c|c|c|}
\hline \multirow{3}{*}{ Cycle } & \multirow{3}{*}{$\begin{array}{l}\text { Sorption } \\
\text { capacity, } \\
\mathrm{A}_{\mathrm{Li}} / \mathrm{A}_{1, \mathrm{Li}}\end{array}$} & \multicolumn{4}{|c|}{ Desorption } \\
\hline & & \multirow{2}{*}{$\begin{array}{c}\mathrm{A}_{\mathrm{Li}}, \\
\mathrm{mmol} \mathrm{g}^{-1}\end{array}$} & \multicolumn{3}{|c|}{$\mathrm{C}($ solution 1$), \mathrm{mmol} \mathrm{dm}^{-3}$} \\
\hline & & & $\mathrm{Li}^{+}$ & $\mathrm{Na}^{+}$ & $\mathrm{K}^{+}$ \\
\hline 1 & 1.00 & 0 & 1.13 & 5.34 & 0.17 \\
\hline 2 & 1.00 & 0.001 & 2.31 & 10.92 & 0.36 \\
\hline 3 & 0.98 & 0 & 3.54 & 16.74 & 0.55 \\
\hline 4 & 1.03 & 0.001 & 4.82 & 22.83 & 0.75 \\
\hline 5 & 1.01 & 0 & 6.16 & 29.22 & 0.96 \\
\hline 6 & 1.04 & 0 & 7.56 & 35.94 & 1.18 \\
\hline 7 & 1.01 & 0.001 & 9.03 & 43.03 & 1.41 \\
\hline 8 & 0.99 & 0.001 & 10.58 & 50.52 & 1.65 \\
\hline 9 & 1.02 & 0 & 12.21 & 58.47 & 1.90 \\
\hline 10 & 0.98 & 0 & 13.94 & 66.93 & 2.17 \\
\hline
\end{tabular}

in Table 2.

After 10 cycles of sorption-desorption, solution 1 was used for obtaining $\mathrm{Li}_{2} \mathrm{CO}_{3}$ and by-product (the mixture of nitrates and carbonates of $\mathrm{K}$ and $\mathrm{Na}$ ) similarly to data reported in ref. [14]. The byproduct can be used as a fertilizer for acidic soils.

\section{Conclusions}

A method for obtaining nanocomposite sorbents (a size of primary particles is $20-30 \mathrm{~nm}$ ), which are selective towards $\mathrm{Li}^{+}$ions, has been proposed. The samples are based on adsorptive active anatase, the selective component being lithium-manganese spinel $\mathrm{LiMn}_{2} \mathrm{O}_{4}$. This component was synthesized preliminarily, its nanoparticles were inserted into the sol of insoluble titanium hydroxocomplexes; the nanocomposite was precipitated from this suspension and then calcined at $500^{\circ} \mathrm{C}$. The optimal amount of $\mathrm{LiMn}_{2} \mathrm{O}_{4}$ is $13 \%$. The sample is obtained in a form of rather large grains $(\sim 0.3 \mathrm{~mm})$; the selectivity coefficient $\mathrm{Li}^{+} / \mathrm{Na}^{+}$is about 500 . The sorbent is regenerated by a $1 \mathrm{M} \mathrm{HNO}_{3}$ solution without manganese leakage. After 10 cycles of sorptiondesorption, the lithium-containing concentrate was obtained; it was applied to $\mathrm{Li}_{2} \mathrm{CO}_{3}$ precipitation. The advantage of the nanocomposite over titaniummanganese sorbent [14] is the ability to use the regenerating solution many times. However, the sorbent requires a higher consumption of this solution.

\section{REFERENCES}

1. Sapse A.M., Schleyer P.R. Lithium chemistry: a theoretical and experimental overview. - New York: John Wiley \& Sons, Inc. 1994. -595 p. 
2. Lithium market research - global supply, future demand and price development / Martin G., Rentsch L., Hock M., Bertau M. // Energy Storage Mater. - 2017. - Vol.6. - P.171-179.

3. Recovery of valuable metals from mixed types of spent lithium ion batteries. Part II. Selective extraction of lithium / Chen X., Cao L., Kang D., Li J., Zhou T., Ma H. // Waste Manage. - 2018. - Vol.80. - P.198-210.

4. Kaunda R.B. Potential environmental impacts of lithium mining // J. Energy Nat. Resour. Law. - 2020. - Vol.38. No. 3. - P.237-244.

5. Lithium metal extraction from seawater / Yang S., Zhang F., Ding H., He P., Zhou H. // Joule. - 2018. - Vol.2. - No. 9. P.1648-1651.

6. Beer K.E., Edmunds W.M., Hawkes J.R. A preliminary look at lithium in the United Kingdom // Energy. - 1978. P.281-292.

7. Safari S., Lottermoser B.G., Alessi D.S. Metal oxide sorbents for the sustainable recovery of lithium from unconventional resources // Appl. Mater. Today. - 2020. - Vol.19. - Article No. 100638.

8. Lithium recovery from aqueous resources and batteries: a brief review / Ling L., Vishwanath D., Paranthaman G., Parans M., Ramesh R., Moyer B., Harrison S. // Johnson Matthey Technol. Rev. - 2018. - Vol.62. - No. 2. - P.161-176.

9. Recovery of lithium from seawater using manganes oxide adsorbent $\left(\mathrm{H}_{1.6} \mathrm{Mn}_{1.6} \mathrm{O}_{4}\right)$ derived from $\mathrm{Li}_{1.6} \mathrm{Mn}_{1.6} \mathrm{O}_{4} /$ Chitrakar R., Kanoh H. Miyai Y., Ooi K. // Ind. Eng. Chem. Res. - 2001. Vol.40. - No. 9. - P.2054-2058.

10. Interaction of sorbed $\mathrm{Ni}$ (II) ions with amorphous zirconium hydrogen phosphate / Dzyazko Yu.S., Trachevskii V.V., Rozhdestvenskaya L.M., Vasilyuk S.L. , Belyakov V.N. // Russ. J. Phys. Chem. A. - 2013. - Vol.87. - No. 5. - P.840-845.

11. Formation of zirconium hydrophosphate nanoparticles and their effect on sorption of uranyl cations / Perlova N., Dzyazko Y., Perlova O., Palchik A., Sazonova V. // Nanoscale Res. Lett. 2017. - Vol.12. - Article No. 209.

12. Structural characteristics and sorption properties of lithium-selective composite materials based on $\mathrm{TiO}_{2}$ and $\mathrm{MnO}_{2} /$ Chaban M.O., Rozhdestvenska L.M., Palchyk O.V., Dzyazko Y.S., Dzyazko O.G. // Appl. Nanosci. - 2019. - Vol.9. - No. 5. P.1037-1045.

13. Chaban M.O., Rozhdestvenska L.M., Dzyazko Y.S. Electromembrane recovery of $\mathrm{Li}^{+}$ions from aqueous solutions using a sorbent based on $\mathrm{TiO}_{2} \cdot \mathrm{MnO}_{2} / /$ Voprosy Khimii i Khimicheskoi Tekhnologii. - 2019. - No. 2. - P.135-143.

14. Chaban M.O., Rozhdestvenska L.M., Palchik O.V. Sorption removal of $\mathrm{Li}^{+}$ions from multicomponent solutions. Regeneration of sorbent and processing of concentrate // osy Khimii i Khimicheskoi Tekhnologii. - 2020. - No. 4. - P.177-186.

15. Ion exchange/adsorption properties of crystalline compound of anatase and rutile / Yinjie S, Liqiang J, Aimin Z, Qixin J, Dakang S. // J. Radioanal. Nucl. Chem. - 1997. Vol.222. - No. 1-2. - P.75-80.

Received 27.01.2021

\section{СЕЛЕКТИВНІ ДО ІОНІВ ЛІТІЮ НАНОКОМПОЗИТНІ СОРБЕНТИ НА ОСНОВІ ТіО, , МО МІСТЯТЬ МАРГАНЦЕВУ ШПІНЕЛЬ}

\section{М.О. Чабан, Л.М. Рождественська, О.В. Пальчик, Л.М. Пономарьова, Ю.С. Дзязько}

Запропоновано спосіб одержання нанокомпозитних сорбентів, які є селективними щодо іонів $\mathrm{Li}^{+}$. Зразки містять адсорбційно активний анатаз, селективним компонентом $€$ літій-марганцева шпінель $\mathrm{LiMn}_{2} \mathrm{O}_{4}$. Цей компонент був попередньо синтезований, і його наночастинки вводили до золю нерозчинних гідроксокомплексів титану, а нанокомпозит осаджували з цієї суспензії і прожарювали при $500^{\circ} \mathrm{C}$. Таким чином одержували ряд сорбентів 3 різним молярним співвідношенням Ti:Mn, що далі були досліджені за допомогою хімічного аналізу, рентгенівської спектроскопії, оптичної мікроскопії, трансмісійної електронної мікроскопії і скануючої електронної мікроскопії Розмір нанокристалітів становить 20-30 нм. Встановлено, що збільшення кількості шпінелі зменшує розмір зерен сорбенту, однак вони механічно довговічні завдяки $\mathrm{TiO}_{2}$, який $є$ зв'язуючою речовиною. Вивчено адсорбцію $\mathrm{Li}^{+} 3$ розчину, що містить надлишок іонів $\mathrm{Na}^{+}$. Встановлено оптимальну кількість $\mathrm{LiMn}_{2} \mathrm{O}_{4}$ (13\%). Зразок отримують у формі досить великих зерен $(\approx 0,3$ мм), коефіцієнт селективності $\mathrm{Li}^{+} / \mathrm{Na}^{+}$становить близько 500. Сорбент регенерують $1 \mathrm{M}$ розчином $\mathrm{HNO}_{3}$ без витоку мангану. Після 10 циклів сорбції-десорбції одержували концентрат, який далі можна використовувати для осадження $\mathrm{Li}_{2} \mathrm{CO}_{3}$.

Ключові слова: анатаз, шпінель, нанокомпозит, літій, адсорбція.

\section{SELECTIVE TO LITHIUM IONS NANOCOMPOSITE SORBENTS BASED ON $\mathrm{TiO}_{2}$ CONTAINING MANGANESE SPINEL}

\section{M.O. Chaban a, *, L.M. Rozhdestvenska ${ }^{a}$, O.V. Palchik ${ }^{a}$, L.M. Ponomarova ${ }^{b}$, Y.S. Dzyazko ${ }^{a}$}

a V.I. Vernadsky Institute of General and Inorganic Chemistry of National Academy of Sciences of Ukraine, Kyiv, Ukraine

b Sumy State University, Sumy, Ukraine

* e-mail: mary.chaban@gmail.com

A method for obtaining nanocomposite sorbents, which are selective towards $\mathrm{Li}^{+}$ions, has been proposed. The samples were based on adsorptive-active anatase, the selective component being lithium-manganese spinel $\mathrm{LiMn}_{2} \mathrm{O}_{4}$. This component was synthesized preliminarily, its nanoparticles were added to the sol of insoluble titanium hydroxocomplexes, and the nanocomposite was precipitated from this suspension and calcined at $500^{\circ} \mathrm{C}$. A number of sorbents with different molar ratio of $\mathrm{Ti}: \mathrm{Mn}$ were prepared via this procedure; they were investigated by means of chemical analysis, X-ray diffraction analysis, optical microscopy, transmission electron microscopy and scanning electron microscopy. The size of nanocrystallites was 20-30 nm. An increase in the spinel amount caused a decrease in the sorbent grain size; however, they the sorbent grains were mechanically durable due to $\mathrm{TiO}_{2}$ which was a binder. Adsorption of $\mathrm{Li}^{+}$from the solution containing an excess of $\mathrm{Na}^{+}$ions was studied. The optimal amount of $\mathrm{LiMn}_{2} \mathrm{O}_{4}(13 \%)$ was determined. The sample was obtained in the form of rather large grains $(\approx 0.3 \mathrm{~mm})$ and the selectivity coefficient $\mathrm{Li}^{+} / \mathrm{Na}^{+}$was about 500 . The sorbent was regenerated by a $1 \mathrm{M} \mathrm{HNO}_{3}$ solution without manganese leakage. After 10 cycles of sorption-desorption, the concentrate was 
obtained. This concentrate can be used for $\mathrm{Li}_{2} \mathrm{CO}_{3}$ precipitation.

Keywords: anatase; spinel; nanocomposite; lithium; adsorption.

\section{REFERENCES}

1. Sapse AM, Schleyer PR, editors. Lithium chemistry: a theoretical and experimental overview. New York: John Wiley \& Sons, Inc.; 1995. 595 p.

2. Martin G, Rentsch L, Hock M, Bertau M. Lithium market research - global supply, future demand and price development. Energy Storage Mater. 2017; 6: 171-179. doi: 10.1016/j.ensm.2016.11.004.

3. Chen X, Cao L, Kang D, Li J, Zhou T, Ma H. Recovery of valuable metals from mixed types of spent lithium ion batteries. Part II. Selective extraction of lithium. Waste Manage. 2018; 80: 198-210. doi: 10.1016/j.wasman.2018.09.013.

4. Kaunda RB. Potential environmental impacts of lithium mining. J Energy Nat Resour Law. 2020; 38: 237-244. doi: 10.1080/02646811.2020.1754596.

5. Yang S, Zhang F, Ding H, He P, Zhou H. Lithium metal extraction from seawater. Joule. 2018; 2: 1648-1651. doi: 10.1016/j.joule.2018.07.006.

6. Beer KE, Edmunds WM, Hawkes JR. A preliminary look at lithium in the United Kingdom. Energy. 1978; 3: 281292. doi: 10.1016/0360-5442(78)90024-5.

7. Safari S, Lottermoser BG, Alessi DS. Metal oxide sorbents for the sustainable recovery of lithium from unconventional resources. Appl Mater Today. 2020; 19: 100638. doi: $10.1016 /$ j.apmt.2020.100638.

8. Ling L, Vishwanath D, Paranthaman G, Parans M, Ramesh R, Moyer B, et al. Lithium recovery from aqueous resources and batteries: a brief review. Johnson Matthey Technol Rev. 2018; 62(2): 161-176. doi: 10.1595/205651317X696676.
9. Chitrakar R, Kanoh H, Miyai Y, Ooi K. Recovery of lithium from seawater using manganese oxide adsorbent $\left(\mathrm{H}_{1.6} \mathrm{Mn}_{1.6} \mathrm{O}_{4}\right)$ derived from $\mathrm{Li}_{1.6} \mathrm{Mn}_{1.6} \mathrm{O}_{4}$. Ind Eng Chem Res. 2001; 40: 2054-2058. doi: 10.1021/ie000911h.

10. Dzyazko YS, Trachevskii VV, Rozhdestvenskaya LM, Vasilyuk SL, Belyakov VN. Interaction of sorbed $\mathrm{Ni}(\mathrm{II})$ ions with amorphous zirconium hydrogen phosphate. Russ $J$ Phys Chem A. 2013; 87: 840-845. doi: 10.1134/S0036024413050063.

11. Perlova N, Dzyazko Y, Perlova O, Palchik A, Sazonova V. Formation of zirconium hydrophosphate nanoparticles and their effect on sorption of uranyl cations. Nanoscale Res Lett. 2017; 12: 209. doi: 10.1186/s11671-017-1987-y.

12. Chaban MO, Rozhdestvenska LM, Palchyk OV, Dzyazko YS, Dzyazko OG. Structural characteristics and sorption properties of lithium-selective composite materials based on $\mathrm{TiO}_{2}$ and $\mathrm{MnO}_{2}$. Appl Nanosci. 2019; 9: 1037-1045.

doi: $10.1007 / \mathrm{s} 13204-018-0749-1$.

13. Chaban MO, Rozhdestvenska LM, Dzyazko YS. Elektromembranne vyluchenn'ya ioniv $\mathrm{Li}^{+} \mathrm{Z}$ vodnykh rozchyniv iz vykorystann'yam sorbentu na osnovi $\mathrm{TiO}_{2} \cdot \mathrm{MnO}_{2}$ [Electromembrane recovery of $\mathrm{Li}^{+}$ions from aqueous solutions using a sorbent based on $\mathrm{TiO}_{2} \cdot \mathrm{MnO}_{2}$ ]. Voprosy Khimii $i$ Khimicheskoi Tekhnologii. 2019; (2): 135-143. (in Ukrainian). doi: 10.32434/0321-4095-2019-123-2-135-143.

14. Chaban MO, Rozhdestvenska LM, Palchik OV. Sorption removal of $\mathrm{Li}^{+}$ions from multicomponent solutions. Regeneration of sorbent and processing of concentrate. Voprosy Khimii i Khimicheskoi Tekhnologii. 2020; (4): 177-186. doi: 10.32434/0321-4095-2020-131-4-177-186.

15. Yinjie S, Liqiang J, Aimin Z, Qixin J, Dakang S. Ion exchange/adsorption properties of crystalline compound of anatase and rutile. J Radioanal Nucl Chem. 1997; 222: 75-80. doi: 10.1007/BF02034250. 